\title{
18F-Fluorodeoxyglucose Positron Emission Tomography/Computed Tomography Imaging in a Patient with HIV (-) Kaposi Sarcoma
}

\author{
HIV (-) Kaposi Sarkomu Olgusunda I8F-Florodeoksiglukoz Pozitron Emisyon Tomografil \\ Bilgisayarlı Tomografı Görüntüleme
}

\author{
Arzu Cengizl, Ekin Şavk2, Canten Tataroğ/u33, Yakup Yüreklil \\ I Adnan Menderes University Faculty of Medicine, Department of Nuclear Medicine, Aydın, Turkey \\ 2Adnan Menderes University Faculty of Medicine, Department of Dermatology, Aydın, Turkey \\ ${ }^{3}$ Adnan Menderes University Faculty of Medicine, Department of Pathology, Aydın, Turkey
}

\begin{abstract}
Kaposi sarcoma (KS) is a vascular neoplasm that often manifests with multiple vascular nodules on the skin and other organs. Various imaging modalities can be used to display disease extent. Herein we present a 65-year-old female patient with human immunodeficiency virus negative KS along with her whole-body positron emission tomography/computed tomography imaging findings.
\end{abstract}

Keywords: Positron emission tomography/computed tomography, kaposi sarcoma, HIV

\section{Öz}

Kaposi sarkomu (KS), deri ve diğer organlarda yaygın vasküler nodüllerle ortaya çıkan vasküler bir tümördür. Hastalığın yaygınlığını göstermek için çeşitli görüntüleme modaliteleri kullanılabilmektedir. Bu çalışmada 65 yaşında insan bağışıklık yetmezlik virüsü negatif KS olan bir kadın hastayı ve bu hastanın tüm vücut pozitron emisyon tomografi/bilgisayarlı tomografi görüntüleme bulgularını sunduk.

Anahtar kelimeler: Pozitron emisyon tomografi/bilgisayarlı tomografi, kaposi sarkomu, HIV

\section{Introduction}

Kaposi sarcoma (KS) is an immunodeficiency syndromerelated disease that has been reported to be strongly associated with human herpes virus-8 $(1,2)$. The skin, mucosal surfaces and lung are the main sites of involvement. Visceral involvement predicts survival especially in patients with acquired immune deficiency syndrome (AIDS)associated $\mathrm{KS}$, thus accurate staging and identification of diseased sites with fluorodeoxyglucose (FDG) positron emission tomography/computed tomography (PET/CT) is useful in the management of these patients (3). Herein we present a patient with human immunodeficiency virus (HIV)-negative KS staged by $18 \mathrm{~F}-\mathrm{FDG}$ PET/CT imaging.

\section{Case Report}

A 65-year-old female patient was referred to our hospital with complaints of swelling and nodular skin lesions on both legs. She had a history of rheumatoid arthritis and treatment with corticosteroid medication for five years. On physical examination, dark blue-purplish macular

Address for Correspondence: Arzu Cengiz MD, Adnan Menderes University Faculty of Medicine, Department of Nuclear Medicine, Aydın, Turkey Phone: +90 2564441256 E-mail: arzukincengiz@gmail.com Received: 29.06.2015 Accepted: 11.12.2015 
and nodular skin lesions were observed on the legs along with pretibial edema (Figure 1). The lesions that had appeared within a few months were not painful. She was diagnosed with KS with biopsy of the skin lesions (Figure 2). Laboratory tests were within normal limits except an elevated erythrocyte sedimentation rate. Anti-HIV antibody was negative. She was referred to our department for initial staging with 18 F-FDG PET/CT imaging. A whole body 18F-FDG PET/CT imaging was performed 60 minutes after 370 megabequerel 18F-FDG injection using an integrated PET/CT scanner (Siemens, Biograph $\mathrm{mCT}$, Germany). 18F-FDG PET/CT imaging showed multiple nodular skin

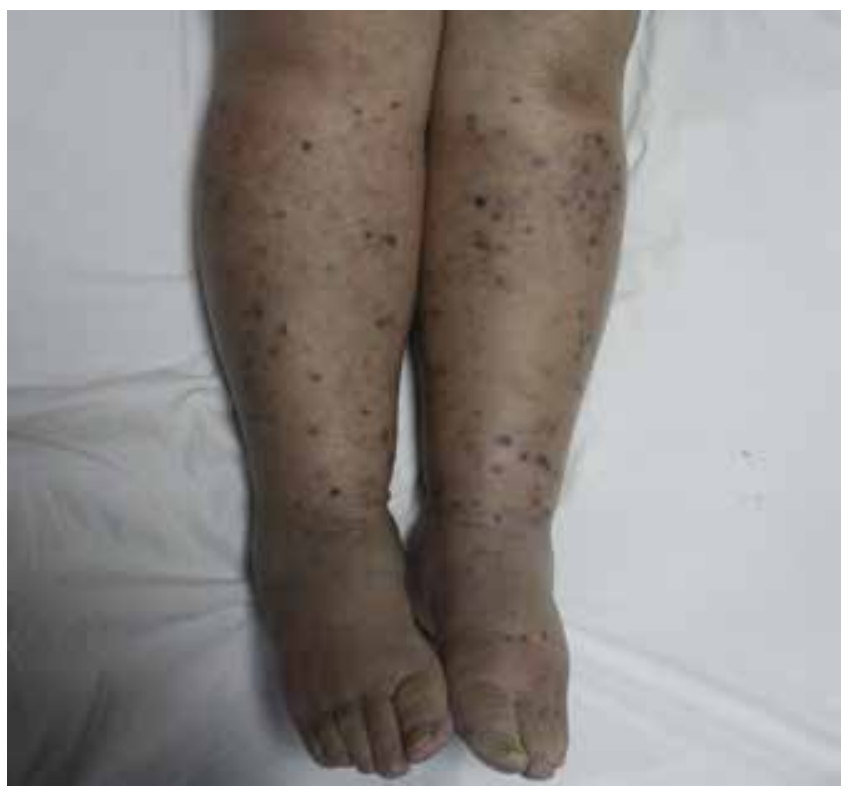

Figure 1. Dark blue-purplish macular and nodular skin lesions on the legs

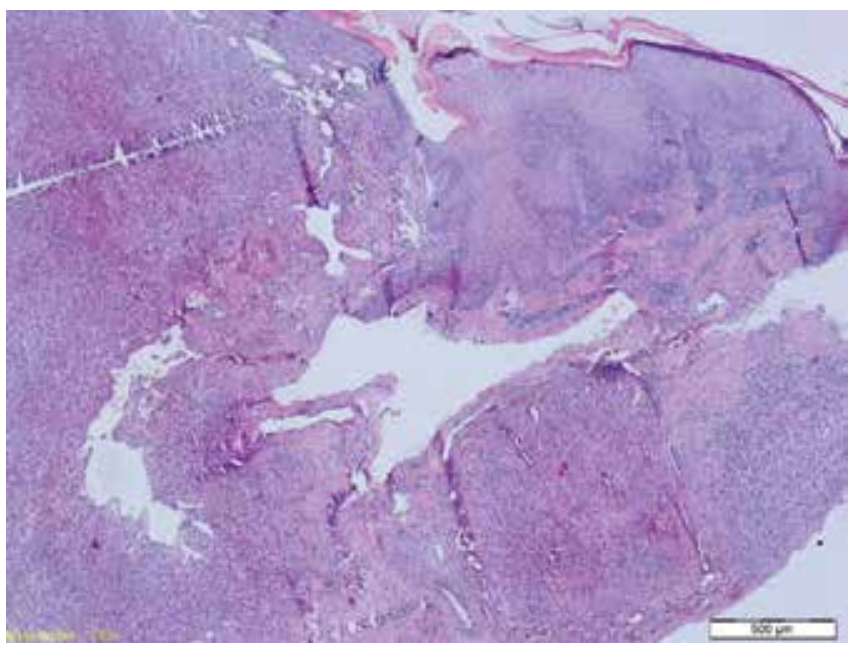

Figure 2. The underlying epidermis spindled cells showing lobular growth pattern (hematoxylin and eosin $\mathrm{x} 40$ ) lesions with increased FDG uptake on both legs (SUV $V_{\max }$ : 6.1). In addition, there were hypermetabolic bilateral inguinal and popliteal lymph nodes (SUV max: 3.6-5.6) (Figure 3).

\section{Literature Review and Discussion}

$\mathrm{KS}$ is a common tumor in AIDS patients. Most patients present with a single or few lesions, however multiple lesions have also been reported (4). In most cases, the lesions are asymptomatic. Four variants of KS have been recognized clinically: classical KS, endemic (African) $\mathrm{KS}$, iatrogenic (organ transplant-related) KS, and AIDSrelated (epidemic) KS (5). Disease stage, clinical type and immune status are important in determining treatment options including surgery, radiotherapy, chemotherapy and immunotherapy. Various imaging modalities including gastrointestinal endoscopy, conventional radiography, $\mathrm{CT}$, magnetic resonance imaging (MRI), and radionuclide imaging are used for staging. Imaging findings depend on the organ systems that are affected. CT and MRI are generally more useful in the assessment of visceral and lymphatic KS. Thoracic disease, which is a common visceral involvement, bilateral hilar lymphadenopathy and bilateral involvement in the mid and lower lung zones with

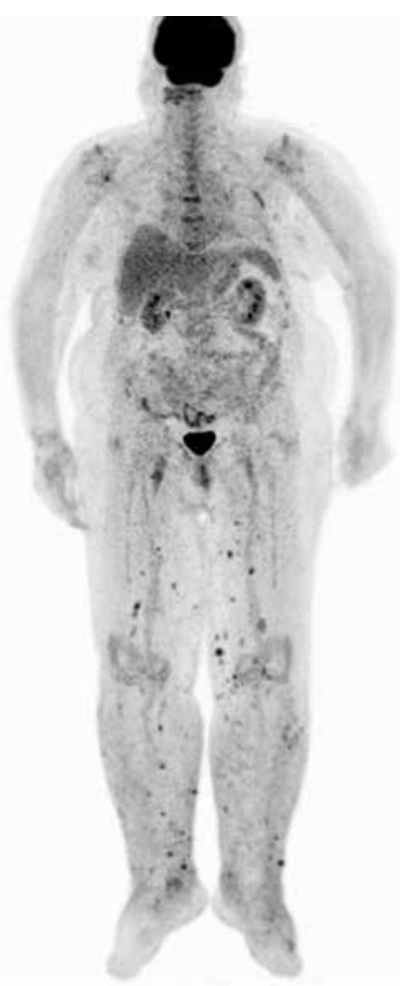

Figure 3. Maximum intensity projection images show multiple nodular lesions with increased fluorodeoxyglucose uptake on the skin and subcutaneous tissues of the legs (SUV max: 6.1), and hypermetabolic lymph nodes at bilateral inguinal and popliteal sites 
peribronchial and perivascular opacities is characteristic on high resolution $\mathrm{CT}$. MRI has higher sensitivity in detecting cardiac lesions and bone involvement $(6,7)$.

Thallium-201 (201TI) and gallium-67 (67Ga) scintigraphy had been previously used for differential diagnosis. ${ }^{67} \mathrm{Ga}$ negative and $201 \mathrm{TI}$ positive lesions were most likely accepted as KS, whereas both ${ }^{67} \mathrm{Ga}$ and ${ }^{201} \mathrm{TI}$ positive lesions were considered as lymphoma (8). 99mTc tetrofosmin had also been once used in patients with KS as a tumor screening agent (9).

Recently, 18F-FDG PET/CT imaging is being used for the evaluation of visceral and lymphatic involvement, and staging of $\mathrm{KS}$. It has a role in both staging and the evaluation of response to therapy $(10,11)$. In addition, PET/CT is an effective method in detecting clinically occult KS lesions that were not detected with other imaging methods (12). KS may demonstrate heterogeneous FDG avidity. In some previous studies, lymph node and visceral involvement such as the bone and lungs were detected by 18F-FDG PET/CT imaging $(10,11,13,14)$. Diffuse and focal FDG uptake in the skin have also been reported $(14,15)$. In our patient, an increased FDG uptake was detected in nodular skin lesions on the lower extremities, and the highest $S U V_{\max }$ value of these lesions was 6.1. 18F-FDG PET/CT imaging detected lymph node involvement in addition to widespread cutaneous involvement in our patient.

In conclusion, whole body 18F-FDG PET/CT imaging can detect the extent of visceral and lymphatic involvement, and makes a significant contribution in both staging and clinical management of KS.

\section{Ethics}

Informed Consent: Consent form was obtained from all participants.

Peer-review: Externally peer-reviewed.

\section{Authorship Contributions}

Surgical and Medical Practices: Ekin Şavk, Concept: Arzu Cengiz, Yakup Yürekli, Design: Arzu Cengiz, Ekin Şavk, Canten Tataroğlu, Data Collection or Processing: Arzu Cengiz, Ekin Şavk, Canten Tataroğlu, Yakup Yürekli, Analysis or Interpretation: Arzu Cengiz, Ekin Şavk, Canten Tataroğlu, Yakup Yürekli, Literature Search: Arzu Cengiz, Writing: Arzu Cengiz, Yakup Yürekli.
Conflict of Interest: No conflict of interest was declared by the authors.

Financial Disclosure: The authors declared that this study has received no financial support.

\section{References}

1. Carbone A. KSHV/HHV-8 associated Kaposi's sarcoma in lymph nodes concurrent with Epstein-Barr virus associated Hodgkin lymphoma. J Clin Pathol 2005;58:626-628.

2. Dupin N, Grange PA. Looking for the target cell of Kaposi's sarcomaassociated herpesvirus. J Invest Dermatol 2006;126:545-547.

3. Krown SE, Testa MA, Huang J. AIDS-related Kaposi's sarcoma: prospective validation of the AIDS Clinical Trials Group staging classification. AIDS Clinical Trials Group Oncology Committee. J Clin Oncol 1997:15:3085-3092.

4. Lin G, Wang H, Fan X, Li H, Wang Z, Lin D, Yang S, Zhang X. Disseminated Kaposi sarcoma in a HIV negative patient. Int J Clin Exp Pathol 2015;8:3378-3380.

5. Tappero JW, Conant MA, Wolfe SF, Berger TG. Kaposi's sarcoma. Epidemiology, pathogenesis, histology, clinical spectrum, staging criteria and therapy. J Am Acad Dermatol 1993;28:371-395.

6. O'Mahony D, Gandjbakche A, Hassan M, Vogel A, Yarchoan R. Imaging techniques for Kaposi's sarcoma. J HIV Ther 2008;13:65-71.

7. Restrepo CS, Ocazionez D. Kaposi's sarcoma: imaging overview. Semin Ultrasound CT MR 2011;32:456-469.

8. Abdel-Dayem HM, Bag R, DiFabrizio L, Aras T, Turoglu HT, Kempf JS, Habbab N, Pescatore F, Sadik A, Kowalsky W. Evaluation of sequential thallium and gallium scans of the chest in AIDS patients. J Nucl Med 1996;37:1662-1667.

9. Spanu A, Ginesu F, Pirina P, Solinas ME, Schillaci O, Farris A, Chessa F, Madeddu G, Marongiu P, Falchi A, Nuvoli S, Madeddu G. The usefulness of $99 \mathrm{mTc}$-tetrofosmin SPECT in the detection of intrathoracic malignant lesions. Int J Oncol 2003:22:639-649.

10. Canbaz F, Ersoy D, Basoglu T. Two cases of 18F-FDG PET/CT findings in HIV-negative Kaposi's sarcoma. Original presentation of one case favorably treated with interferon. Hell J Nucl Med 2011;14:74-75.

11. Morooka M, Ito K, Kubota K, Minamimoto R, Shida $Y$, Hasuo K, Ito T, Tasato D, Honda H, Teruya K, Kikuchi Y, Ohtomo K. Wholebody 18F-fluorodeoxyglucose positron emission tomography/ computed tomography images before and after chemotherapy for Kaposi sarcoma and highly active antiretrovirus therapy. Jpn J Radiol 2010;28:759-762.

12. Sathekge $M$, Maes A, Van de Wiele C. FDG-PET imaging in HIV infection and tuberculosis. Semin Nucl Med 2013;43:349-366.

13. Reuter $S$, Vrachimis A, Huss $S$, Wardelmann $E$, Weckesser $M$, Pavenstadt $\mathrm{H}$. A challenging case of rapid progressive Kaposi sarcoma after renal transplantation: diagnostics by FDG PET/CT. Medicine (Baltimore) 2014;93:e67.

14. Ozdemir E, Poyraz NY, Keskin M, Kandemir Z, Turkolmez S. (18) F-FDG PET/CT findings in a case with HIV (-) Kaposi sarcoma. Rev Esp Med Nucl Imagen Mol 2014;33:175-177.

15. Sager S, Engin B, Kutlubay Z, Asa S, Sager SG, Gucluer B, Kanmaz B. PET/CT imaging of HIV-negative Kaposi's sarcoma. Ir J Med Sci 2013;182:745-746. 